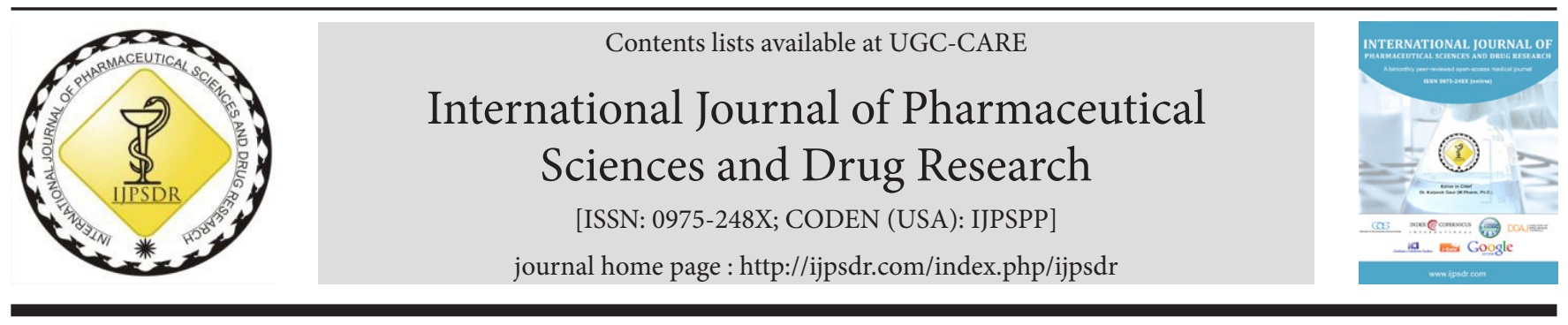

Research Article

\title{
Probiotic Potential and Safety Characterization of Enterococcus hirae G24 isolated from Indigenous Raw Goat Milk
}

\author{
Kamni Rajput , Ramesh Chandra Dubey \\ Department of Botany and Microbiology, Gurukula Kangri Vishwavidyalaya, Haridwar-249404, Uttarakhand, India
}

\begin{tabular}{l} 
A R T I C L E I N F O \\
\hline Article history: \\
Received: 21 January, 2020 \\
Revised: 12 April, 2020 \\
Accepted: 27 April, 2020 \\
Published: 30 May, 2020 \\
Keywords: \\
Enterococcus hirae, Goat milk, \\
Lactic acid bacteria, Probiotic, \\
Probiotic attributes safety \\
parameters. \\
D0I: \\
10.25004/IJPSDR.2020.120303
\end{tabular}

\begin{abstract}
A B S T R A C T
In this paper, an investigation on lactic acid bacterial isolates from ethnic goat raw milk samples were examined for their probiotic potential and safety parameters. For this purpose, isolated bacterial cultures were screened based on certain parameters, viz., sugar fermentation, tolerance to temperature, salt, low $\mathrm{pH}$, bile salts, and phenol resistance. After that, these bacterial cultures were more estimated in vitro for auto-aggregation, cell surface hydrophobicity, response to simulated stomach duodenum channel, antibiotic resistance, and antimicrobial activity. Besides, probiotic traits show the absence of gelatinase, and hemolytic activity supports its safety. The isolate G24 showed good viability at different $\mathrm{pH}$, bile concentration, phenol resistance, and response to simulated stomach duodenum passage, but it did not show gelatinase and hemolytic activities. Isolate G24 was susceptible to amikacin, carbenicillin, kanamycin, ciprofloxacin, co-trimazine, nitrofurantoin, streptomycin, and tetracycline. Isolate G24 also exhibited antimicrobial action against five common pathogenic bacteria, such as, Escherichia coli, Staphylococcus aureus, Pseudomonas aeruginosa, Listeria monocytogens, and Salmonella typhimurium. It displayed the maximum auto-aggregation, cell surface hydrophobicity to different hydrocarbons. Following molecular characterization, the isolate G24 was identified as Enterococcus hirae with $16 \mathrm{~S}$ rRNA gene sequencing and phylogeny. E. hirae G24 bears the excellent properties of probiotics.
\end{abstract}

\section{INTRODUCTION}

Fresh milk and nutritious milk food are introducing a complex probiotic microbiota. Fresh milk is commonly recognized that the lactic acid bacteria (LAB), including Enterococcus genus, are the prevailing population, such as, cow, goat, sheep, and buffalo milk. ${ }^{[1]}$ Goats were among the main farm animals to be tamed for about numerous years. ${ }^{[2]}$ Goat milk contains lipids, protein, carbohydrates, vitamins, and minerals. Its composition is a higher correlation with other bovine milk except for the presence of a low amount of lactose. Milk fat globules are littler and perhaps, one of the explanations behind the simple processing of this milk. High source of protein, fat, phosphate, and calcium are found in goat milk products. Its composition depends on many factors, such as, diet, assortment, environment, and conditions. Goat milk has better absorbability, alkalinity, buffering capacity, and certain remedial qualities in medication and human nutrition than that of other bovine milk. ${ }^{[3]}$

Enterococci are gram-positive, catalase-negative, no spore-forming cocci, and occur in vegetables, plant materials, and various dairy products. Enterococci relate to lactic acid bacteria and significant in food due to fermentation as probiotics in human and animals. Enterococci directly contribute to the distinctive flavor and taste of traditional dairy products. They also protect many fermented foods, such as, sausages, cheese, and dairy products. $^{[4]}$ Several species of Enterococcus have been commonly used as probiotics in humans and animals for the cure of gastroenteritis. ${ }^{[5]}$

Probiotics are also used in microbial food supplements, which apply different human health medical advantages,

\footnotetext{
*Corresponding Author: Kamni Rajput

Address: Department of Botany and Microbiology, Gurukula Kangri Vishwavidyalaya, Haridwar-249404, Uttarakhand, India

Email $\bowtie$ : kamnirajput20@gmail.com

Tel.: +91-8954541157

Relevant conflicts of interest/financial disclosures: The authors declare that the research was conducted in the absence of any commercial or financial relationships that could be construed as a potential conflict of interest.

Copyright (C) 2020 Kamni Rajput et al. This is an open access article distributed under the terms of the Creative Commons Attribution- NonCommercialShareAlike 4.0 International License which allows others to remix, tweak, and build upon the work non-commercially, as long as the author is credited and the new creations are licensed under the identical terms.
} 
when administered in acceptable quantities, especially to the digestive system. ${ }^{[6]} \mathrm{A}$ lot of probiotic bacteria, particularly lactic acid bacteria, are available in milk. Probiotics are the most lactic acid bacteria engaged with food, drinks, dairy products, which are used as consummation products. The achievement of these bacteria in the market relies upon the proficiency of the way of life used as probiotic. Actual probiotic bacteria should be acid and bile tolerant, capable of surviving in the gastrointestinal tract. ${ }^{[7]}$ The LAB produces different antimicrobial substances, i.e., organic acid, bacteriocins, etc., against numerous pathogenic microbes. Such antimicrobial metabolites diminish the evolution of pathogenic microbes in the gut. ${ }^{[8]}$ The resistance of phenol is one of the selection criteria. The expected use of probiotics to adjust the gastrointestinal prosperity, such as, rising regular assurance from infective disease, improving lactose intolerance, reduce stomach related tract issue. ${ }^{[9]}$ The ability of probiotic bacteria to adhere to the epithelial cell is a significant determination for potential probiotic strains. The adherence ability of bacteria to gut surface supports by bacterial adhesion to hydrocarbon (BATH) to improve their interaction with the host. ${ }^{[10]}$

$E$. hirae is a lactic acid bacterium because of the presence of particular probiotic properties, and it can suffer $\mathrm{NaCl}$ concentrations, low $\mathrm{pH}$ and bile tolerance, and phenol resistance. It has antimicrobial activity against intestinal pathogenic microorganisms. Because of the previously mentioned properties, probiotics have found a place in pharmaceutical plans and are provided as pharma products. ${ }^{[11]}$ In the pharma companies, probiotic details can be viewed as either dietary enhancements or medication. The combinations of probiotic strains form probiotic products. These probiotic products are accessible as powder, capsule, tablets, drops, chewing gum, bottle caps, etc., in the market, but mostly probiotics are available in the form of capsules. ${ }^{[12]}$ The objective of this investigation was to assess the probiotic capability of E. hirae G24 isolated from fresh milk of goat, for their possible use in the field of pharma and medical.

\section{Materials AND METHODS}

\section{Assortment of Samples, Isolation, and Preservation of Bacterial Isolates}

The bacterial cultures were isolated from raw milk of goat, which were collected into sterile bottles from different ranges of Haridwar. The bacterial isolates were screened by using a tenfold serial dilution method and were spread onto De Man, Rogosa and Sharpe (MRS) agar medium plates with bromocresol purple (BSP). These spread MRS plates were incubated for 24 to 48 hours at $37^{\circ} \mathrm{C}$ for the growth of bacteria. After the incubation period, yellow color colonies appeared, which is a characteristic of lactic acid bacteria on MRS agar plates and picked the colonies for morphological assessment. These particular colonies were streaked on MRS plates. Selected bacterial cultures were preserved on MRS agar slants at $4^{\circ} \mathrm{C}^{[13]}$

\section{Physiological and Biochemical Characterization of Isolates}

Lactic acid bacterial isolates were scanned morphological and biochemical. These characterizations of isolates were done microscopically through Gram's staining and endospore staining. These isolates were additionally assessed for catalase, oxidase, citrate utilization, indole, methyl red, and Voges-Proskauer tests. ${ }^{[14]}$

\section{Analysis of Probiotic Properties}

\section{Sugar Fermentation Test}

Five different sugars, viz., glucose, sucrose, maltose, fructose, and dextrose were used for sugar fermentation assay. Fresh bacterial cultures were independently inoculated into sterilized different sugar fermentation broth and incubated at $37^{\circ} \mathrm{C}$ for 24 hours. The fermentation of sugar was observed by a change of medium color from the original red to yellow color because of acid production. ${ }^{[15]}$

\section{Temperature Tolerance}

Overnight grown bacterial cultures were separately inoculated into five different tubes of MRS broth. These tubes were incubated at different temperatures, such as, $4,15,25,37$, and $45^{\circ} \mathrm{C}$ for 48 hours. The turbidity of the bacterial growth of the isolates was observed at $610 \mathrm{~nm}^{[16]}$

\section{Salt Tolerance}

Bacterial isolates were grown in MRS broth supplemented with various concentrations of salt, such as, 2, 4, 6, and 8\% at $37^{\circ} \mathrm{C}$ for 24 hours. After incubation, development was resolved to utilize a spectrophotometer (Shimadzu, Japan), examining the optical density at $610 \mathrm{~nm} .{ }^{[17]}$

\section{Acid Tolerance}

The bacterial isolates were incubated in MRS broth at $37^{\circ} \mathrm{C}$ for 24 hours. Actively grown isolates were inoculated into different $\mathrm{pH}(2.0,4.0)$ adjusted MRS broth with $1 \mathrm{~N} \mathrm{HCl}$ and incubated at $37^{\circ} \mathrm{C}$. MRS broth changed by pH 6.5 was utilized as a control. Samples were withdrawn with an interval of 0,2 , and 4 hours, and these samples serially diluted. Samples were pouring on MRS agar plates and incubated at $37^{\circ} \mathrm{C}$ for 24 to 48 hours. After 48 hours, cell possibility was estimated by the plate count method. ${ }^{[17]}$

\section{Bile Salt Tolerance}

MRS broth containing $0.5,1$, and $2 \%$ bile salt concentration with fresh bacterial cultures were incubated at $37^{\circ} \mathrm{C}$ and withdrawn at 0,4 , and 24 hours to enumerate cell viability by plate count method. ${ }^{[17]}$ 
Enterococcus hirae G24 isolated from goat milk

\section{Phenol Resistance}

Harvested bacterial cultures were inoculated in MRS broth with a $0.4 \%$ phenol concentration. Cell viability of samples was determined by the cell plate count technique after withdrawn at an interval of 0,4 , and 24 hours. ${ }^{[18]}$

\section{Antimicrobial Activity}

Antimicrobial action of particular bacterial isolates against pathogenic microorganisms was completed by the agar well diffusion technique. Five various pathogenic microorganisms, viz., Escherichia coli (MTCC118), Staphylococcus aureus (MTCC7443), Pseudomonas aeruginosa (MTCC424), Listeria monocytogens (MTCC657), and Salmonella typhimurium (MTCC733) were acquired from the Institute of Microbial Technology (IMTECH), Chandigarh (India), and used as an indicator. Each pathogenic bacterial suspension was swabbed on MullerHinton Agar (MHA) plates. Wells were arranged using a cork borer $(6 \mathrm{~mm})$ on the each swabbed MHA plates. Overnight grown bacterial cultures were separately centrifuged at 4,000 rpm for 15 minutes. Cell-free supernatant (CFS) of isolates was poured into wells on the plates by using a micropipette and incubated at $37^{\circ} \mathrm{C}$ for 24 hours. After incubation, the zone of inhibition against pathogens was evaluated. ${ }^{[19]}$

\section{Auto-Aggregation Assay}

Fresh bacterial cultures were harvested by centrifugation at 6,000 rpm for 10 minutes. Bacterial cell pellets washed twice with phosphate buffer saline (PBS). These cell pellets were suspended in PBS and adjusted to preliminary an absorbance of 0.5 at $600 \mathrm{~nm}\left(\mathrm{Abs}_{\text {initial }}\right)$. The cell pellets suspension was re-centrifuged, and pellets resuspended in an equal volume of MRS broth and incubated at $37^{\circ} \mathrm{C}$ for 2 and 4 hours. From that point on, $1 \mathrm{~mL}$ of the upper suspension was withdrawn to evaluate the absorbance $\left(\mathrm{Abs}_{\text {final }}\right)$ utilizing MRS broth. ${ }^{[20]}$ Auto-aggregation rate was determined by the following equation:

Auto-aggregation $(\%)=\left(O D_{\text {initial }}-\mathrm{OD}_{\text {final }}\right) / O D_{\text {initial }} \times 100$

\section{Cell Surface Hydrophobicity}

The bacterial cultures were grown in MRS broth overnight. This harvested culture centrifuged at 6,000 rpm for 10 minutes. Cell pellets were washed 2 to 3 times with phosphate urea magnesium (PUM) buffer ( $\mathrm{pH}$ 6.5) and pellets suspended in PUM by using vortex and acclimated to starting absorbance $\left(\mathrm{Abs}_{\text {initial }}\right)$ of 0.7 to 0.9 at $610 \mathrm{~nm}$. The cell suspension ( $3 \mathrm{~mL}$ ) was independently poured in various tubes containing $1 \mathrm{~mL}$ hydrocarbons (xylene and $n$-hexadecane) and incubated at $37^{\circ} \mathrm{C}$ for 1 -hour. The mixture was again vortex for 1 to 2 minutes and incubated at $37^{\circ} \mathrm{C}$ for 1 -hour. The tubes were kept undisturbed to allow the phase separation. After 1 -hour, the aqueous phase was expelled by micropipette and transferred into another tube, and the last absorbance $\left(\mathrm{Abs}_{\text {final }}\right)$ was measured at 610 $n m$ by utilizing a spectrophotometer (Shimadzu, Japan). ${ }^{[21]}$

$$
\text { Hydrophobicity }(\%)=\left(O D_{\text {initial }}-O D_{\text {final }}\right) / O D_{\text {initial }} \times 100
$$

Response to Simulated Stomach Duodenum Passage (SSDP) Harvested overnight bacterial cultures mixed in MRS broth with $\mathrm{pH}$ 2.0. Preliminary counts of samples by spread plate method. These samples were incubated for 1-hour at $37^{\circ} \mathrm{C}$, and cell viability counts. Then, $4 \mathrm{~mL}$ of oxbile solution was added to the sample, followed by $17 \mathrm{~mL}$ of synthetic duodenum juice $\left(6.4 \mathrm{~g} / \mathrm{L} \mathrm{NaHCO}_{3}, 0.239 \mathrm{~g} / \mathrm{L} \mathrm{KCl}\right.$, $1.28 \mathrm{~g} / \mathrm{L} \mathrm{NaCl}$, and pH 7.4). Samples were incubated at $37^{\circ} \mathrm{C}$ for 2 and 4 hours, and suitable viable counts by spread plating. ${ }^{[22]}$

\section{Antibiotic Sensitivity Test}

The antibiotic disc diffusion technique of the National Committee for Clinical Laboratory Standards was resolved to the antibiotic disc diffusion method. ${ }^{[23]}$ Fresh bacterial cultures were swabbed on the MRS agar plates and allowed to dry. Antibiotic disks were situated on the agar surface and incubated at $37^{\circ} \mathrm{C}$. The zone of inhibition was estimated against disk after 24 hours of incubation.

\section{Gelatinase Hydrolysis Test}

Overnight grown fresh lab isolates were stabbed into the sterile nutrient gelatin deep slants and incubated at $37^{\circ} \mathrm{C}$ for 48 hours. After the incubation period, slants were placed into a refrigerator at $4^{\circ} \mathrm{C}$ for 10 to 15 minutes and slants were observed (negative reaction for gelatin solidification and positive reaction for gelatin hydrolysis). This pathogenic bacteria $S$. aureus was used as a positive control. ${ }^{[24]}$

\section{Hemolysis Activity Test}

Blood agar base with fresh 10\% human blood collected in EDTA tube was used for the hemolytic activity. Fresh bacterial cultures were streaked on the sterile blood agar plates and incubated at $37^{\circ} \mathrm{C}$ for 24 hours. The zone of hemolysis around the colonies was examined. S. aureus was used for positive control. ${ }^{[25]}$

\section{Molecular Identification}

Out of the five isolates, G24 possessed the maximum probiotic potential. Therefore, it was used for molecular identification. Pure culture of isolate G24 was grown in MRS medium to get the log phase culture. Genomic DNA was separated after the technique for Sambrook and Russel (2001). ${ }^{[26]}$ The primers 27F (5'-AGA GTT TGA TCM TGG CTC AG-3') and 1492R (5'-TAC GGY TAC CTT GTT ACG ACT T-3') with 16S rRNA gene was used. By utilizing ClustalW at NCBI, bacterial strains sequence closest to the isolate G24 was recovered and adjusted. The phylogenetic examination was accomplished by using MEGA version 7. $16 \mathrm{~S}$ rRNA bacterial gene sequence was submitted to the Gene Bank of NCBI and got the accession number.

\section{Statistical Analysis}

All the experiments were carried out in triplicate. The results are presented as mean values and standard error 
of triplicates. The data were analyzed by using Mircosoft Excel 2010.

\section{RESULTS}

\section{Collection of Samples, Isolation, and Maintenance of Bacterial Isolates}

A complete 43 bacterial isolates were grown on MRS medium containing bromocresol purple from 15 goat crude milk samples. Change yellow color colonies (below pH 5.2) in the presence of lactic acid from its initial purple color (above pH 6.8) by bromocresol purple (BCP) dye, which is used as a $\mathrm{pH}$ marker. Therefore, yellow color colonies of LAB are picked from the MRS agar plates. Out of 15 isolates, only five isolates were screened through physiological and biochemical characters along with the probiotic attributes tests. These isolates were gram positive and negative for catalase, oxidase, citrate utilization, indole, methyl red, Voges Proskauer tests, and endospore formation (Table 1).

\section{Probiotic Properties Analysis}

Sugar Fermentation Test

The picked LAB isolates were grown in sugar fermentation medium containing various carbohydrates and was inspected for change in shading from red to yellow, which shows the formation of lactic acid. Every selected LAB isolate was capable of yielding lactic acid from lactose (Table 2).

\section{Temperature and Salt Tolerance}

The isolates G14 and G24 survived at temperatures 4, 15, 25,37 , and $45^{\circ} \mathrm{C}$, but G32, G16, and G20 isolates could not grow at temperatures 4 and $45^{\circ} \mathrm{C}$. All selected isolates were able to grow at 2 and $4 \%$ salt concentrations, whereas the isolate G24 fairly grew at 6 and $8 \%$ salt concentrations, but other isolates were completely failed to grow at this concentration (Table 2).

\section{Acid Tolerance}

All selected isolates were assessed for all out viable counts

Table 1: Morphological and biochemical characteristics of bacterial isolates

\begin{tabular}{llllll}
\hline \multicolumn{1}{c}{ Bacterial isolates } & & & \\
\cline { 2 - 5 } Parameters & G14 & $G 15$ & $G 20$ & G24 & +, cocci \\
\hline Gram staining &,+ rod & + , rod & + , cocci & - & - \\
Endospore test & - & - & - & - & - \\
Catalase test & - & - & - & - & - \\
Oxidase test & - & - & - & - & - \\
Citrate utilization test & - & - & - & - \\
Indole test & - & - & - & - \\
Methyl red test & - & - & - & - \\
Voges Prausker test & - & - & & - \\
\hline
\end{tabular}
+ = positive; - = negative

Table 2: Temperature, salt tolerance, and sugar fermentation test of isolates

\begin{tabular}{|c|c|c|c|c|c|c|}
\hline \multirow[b]{3}{*}{ Parameters } & & \multicolumn{5}{|c|}{ Goat milk } \\
\hline & & \multicolumn{5}{|c|}{ Bacterial isolates } \\
\hline & & G14 & G16 & G20 & $G 24$ & G32 \\
\hline \multirow{5}{*}{ Temperature $\left({ }^{\circ} \mathrm{C}\right)$} & 4 & + & + & + & + & - \\
\hline & 15 & + & + & + & + & + \\
\hline & 25 & + & + & + & + & + \\
\hline & 37 & + & + & + & + & + \\
\hline & 45 & + & - & - & + & + \\
\hline \multirow{4}{*}{$\mathrm{NaCl}$ tolerance (\%) } & 2 & + & + & + & + & + \\
\hline & 4 & + & + & + & + & + \\
\hline & 6 & - & + & + & + & + \\
\hline & 8 & - & - & - & + & - \\
\hline \multirow{5}{*}{ Sugars fermentation } & Glucose & + & + & + & + & + \\
\hline & Sucrose & $+/-$ & + & + & + & + \\
\hline & Maltose & $+/-$ & + & $+/-$ & + & $+/-$ \\
\hline & Fructose & + & $+/-$ & + & + & + \\
\hline & Dextrose & + & + & $+/-$ & + & + \\
\hline
\end{tabular}


at various concentrations of $\mathrm{pH}(2.0,4.0$, and 6.5). All five isolates survived at different $\mathrm{pH}$ ranges. The isolate G24 survived well with the most extreme cell viability for 2 to 4 hours when contrasted with the different isolates (Table 3).

\section{Bile Salt Tolerance}

The lab isolates were screened for their ability to tolerate bile salt concentrations of $0.5,1$, and $2 \%$ at an interval of 0,4 , and 24 hours incubation. The isolate G24 displayed the extreme cell viability as compared to the different isolates (Table 4).

\section{Phenol Resistance}

The bacterial isolates were detected in a $0.4 \%$ phenol solution supplemented with MRS broth throughout the interval of 0,4 , and 24 hours. All isolates survived and multiplied on the wide concentrations of phenol solution. The G24 isolate displayed the most extreme cell numbers (Table 5).

Table 3: Effect of different $\mathrm{pH}$ on survival of isolates

\begin{tabular}{|c|c|c|c|c|c|c|c|c|c|}
\hline \multirow{3}{*}{$\begin{array}{l}\text { Bacterial } \\
\text { isolates }\end{array}$} & \multicolumn{9}{|c|}{ Acid tolerance (viable counts, $\log C F U / m L$ )* } \\
\hline & \multicolumn{3}{|l|}{ pH 2.0} & \multicolumn{3}{|l|}{ pH 4.0} & \multicolumn{3}{|l|}{$p H 6.5$} \\
\hline & $0 h r$ & $2 \mathrm{hr}$ & $4 h r$ & $O \mathrm{hr}$ & $2 h r$ & $4 h r$ & $0 \mathrm{hr}$ & $2 h r$ & $4 h r$ \\
\hline G14 & $5.7 \pm 0.23$ & $3.8 \pm 0.06$ & $3.1 \pm 0.08$ & $6.9 \pm 0.14$ & $4.2 \pm 0.27$ & $3.1 \pm 0.2$ & $7.9 \pm 0.15$ & $8.4 \pm 0.15$ & $9.5 \pm 0.28$ \\
\hline G16 & $3.7 \pm 0.12$ & $2.4 \pm 0.2$ & $1.6 \pm 0.12$ & $4.6 \pm 0.24$ & $3.4 \pm 0.12$ & $2.7 \pm 0.08$ & $5.6 \pm 0.14$ & $6.5 \pm 0.21$ & $7.8 \pm 0.03$ \\
\hline G20 & $4.5 \pm 0.23$ & $2.5 \pm 0.23$ & $1.7 \pm 0.05$ & $5.6 \pm 0.15$ & $3.5 \pm 0.14$ & $2.6 \pm 0.24$ & $6.6 \pm 0.24$ & $7.5 \pm 0.2$ & $8.6 \pm 0.2$ \\
\hline G24 & $7.3 \pm 0.32$ & $5.2 \pm 0.13$ & $4.2 \pm 0.29$ & $8.0 \pm 0.17$ & $6.3 \pm 0.29$ & $5.3 \pm 0.15$ & $8.6 \pm 0.08$ & $9.9 \pm 0.11$ & $10.8 \pm 0.08$ \\
\hline G32 & $6.1 \pm 0.11$ & $4.7 \pm 0.08$ & $3.2 \pm 0.14$ & $6.9 \pm 0.08$ & $5.2 \pm 0.23$ & $4.3 \pm 0.35$ & $7.7 \pm 0.03$ & $8.3 \pm 0.11$ & $9.3 \pm 0.23$ \\
\hline
\end{tabular}

*value of mean of triplicate \pm standard error

Table 4: Effect of different bile concentrations on survival of isolates

\begin{tabular}{|c|c|c|c|c|c|c|c|c|c|}
\hline \multirow{3}{*}{$\begin{array}{l}\text { Bacterial } \\
\text { isolates }\end{array}$} & \multicolumn{9}{|c|}{ Bile tolerance (viable cell counts, $\log \mathrm{CFU} / \mathrm{mL}$ )* } \\
\hline & \multicolumn{3}{|l|}{$0.5 \%$} & \multicolumn{3}{|l|}{$1 \%$} & \multicolumn{3}{|l|}{$2 \%$} \\
\hline & $0 h r$ & $4 h r$ & $24 h r$ & $0 h r$ & $4 h r$ & $24 h r$ & $O \mathrm{hr}$ & $4 h r$ & $24 h r$ \\
\hline G14 & $7.9 \pm 0.08$ & $7.3 \pm 0.06$ & $6 \pm 0.05$ & $7.3 \pm 0.26$ & $6.4 \pm 0.21$ & $5.5 \pm 0.16$ & $6.4 \pm 0.23$ & $5.6 \pm 0.15$ & $4.4 \pm 0.17$ \\
\hline G16 & $7.3 \pm 0.17$ & $6.4 \pm 0.2$ & $4 \pm 0.20$ & $5.5 \pm 0.2$ & $4.5 \pm 0.2$ & $3.2 \pm 0.24$ & $3.7 \pm 0.15$ & $3.3 \pm 0.21$ & $1.7 \pm 0.15$ \\
\hline G20 & $8.8 \pm 0.17$ & $8.0 \pm 0.26$ & $6.7 \pm 0.08$ & $7.4 \pm 0.12$ & $6.3 \pm 0.08$ & $5.6 \pm 0.14$ & $8.6 \pm 0.12$ & $5.3 \pm 0.08$ & $4.3 \pm 0.18$ \\
\hline G24 & $9.9 \pm 0.08$ & $8.6 \pm 0.18$ & $7.4 \pm 0.16$ & $8.3 \pm 0.17$ & $7.5 \pm 0.23$ & $6.5 \pm 0.12$ & $8.9 \pm 0.03$ & $7.7 \pm 0.08$ & $6.7 \pm 0.3$ \\
\hline G32 & $6.8 \pm 0.11$ & $6.1 \pm 0.12$ & $5.6 \pm 0.05$ & $5.9 \pm 0.03$ & $5.0 \pm 0.05$ & $4.3 \pm 0.11$ & $4.8 \pm 0.05$ & $3.7 \pm 0.11$ & $2.8 \pm 0.12$ \\
\hline
\end{tabular}

*value of mean of triplicate \pm standard error

Table 5: Effect of phenol concentration on survival of isolates

\begin{tabular}{|c|c|c|c|}
\hline \multirow[b]{3}{*}{ Bacterial isolates } & \multicolumn{3}{|c|}{ Phenol tolerance $(\log C F U / m L) *$} \\
\hline & \multicolumn{3}{|c|}{$0.4 \%$ concentration of phenol } \\
\hline & $0 \mathrm{hr}$ & $4 h r$ & $24 h r$ \\
\hline G14 & $15.5 \pm 0.21$ & $11.6 \pm 0.08$ & $8.5 \pm 0.08$ \\
\hline G16 & $13.5 \pm 0.23$ & $11.3 \pm 0.24$ & $7.4 \pm 0.14$ \\
\hline G20 & $16.7 \pm 0.18$ & $13.5 \pm 0.2$ & $9.3 \pm 0.12$ \\
\hline G24 & $18.8 \pm 0.05$ & $16 \pm 0.49$ & $13.7 \pm 0.26$ \\
\hline G32 & $12.3 \pm 0.14$ & $10.9 \pm 0.14$ & $6.5 \pm 0.17$ \\
\hline
\end{tabular}


Kamni Rajput et al.

Table 6: Antimicrobial activity of cell-free supernatant of isolates against pathogens

\begin{tabular}{llllll}
\hline \multirow{2}{*}{$\begin{array}{l}\text { Bacterial } \\
\text { isolates }\end{array}$} & \multicolumn{5}{l}{ Zone of inhibition $(\mathrm{mm})^{*}$} \\
\cline { 2 - 6 } & E. coli & P. aeruginosa & S. aureus & L. monocytogens & S. typhimurium \\
\hline G14 & $11.7 \pm 0.88$ & $15.7 \pm 0.33$ & $15.3 \pm 0.33$ & $13.7 \pm 0.66$ & $12.7 \pm 0.33$ \\
G16 & $10.3 \pm 0.33$ & $16.7 \pm 0.66$ & $13 \pm 0.57$ & $12.3 \pm 0.33$ & $14.7 \pm 0.33$ \\
G20 & $11.3 \pm 0.66$ & $14 \pm 0.57$ & $15.7 \pm 0.66$ & $12 \pm 0.57$ & $14.3 \pm 0.33$ \\
G24 & $13.7 \pm 0.33$ & $18.7 \pm 0.33$ & $17.3 \pm 0.66$ & $20.3 \pm 0.88$ & $16 \pm 0.57$ \\
G32 & $12 \pm 0.57$ & $14.7 \pm 0.88$ & $11.7 \pm 0.33$ & $14 \pm 0.57$ & $13.7 \pm 0.88$ \\
\hline
\end{tabular}

*value of mean of triplicate \pm standard error

Table 7: Auto-aggregation ability of selected isolates

\begin{tabular}{lll}
\hline & \multicolumn{2}{l}{ Auto-aggregation (\%) } \\
\cline { 2 - 3 } Bacterial isolates & $4 \mathrm{hr}$ & $6 \mathrm{hr}$ \\
\hline G14 & $24 \pm 0.65$ & $35.2 \pm 0.9$ \\
G16 & $20.4 \pm 0.49$ & $29.8 \pm 0.84$ \\
G20 & $19.8 \pm 0.38$ & $26.6 \pm 0.62$ \\
G24 & $44 \pm 0.12$ & $55 \pm 0.46$ \\
G32 & $32.9 \pm 0.56$ & $41 \pm 0.63$ \\
\hline
\end{tabular}

Table 8: Cell surface hydrophobicity of bacterial isolates

Value of mean of triplicate \pm standard error

Table 9: Response to simulated stomach duodenum passage of bacterial isolates

\begin{tabular}{lll}
\hline \multirow{2}{*}{$\begin{array}{l}\text { Bacterial } \\
\text { isolates }\end{array}$} & \multicolumn{2}{l}{ Cell surface hydrophobicity (\%) } \\
\cline { 2 - 3 } & $n$-hexadecane & xylene \\
\hline G14 & $37.1 \pm 0.49$ & $32.4 \pm 0.44$ \\
G16 & $22.6 \pm 0.67$ & $34 \pm 1.03$ \\
G20 & $17.3 \pm 0.48$ & $28.2 \pm 0.33$ \\
G24 & $47.9 \pm 0.48$ & $51.9 \pm 0.4$ \\
G32 & $40.9 \pm 0.39$ & $21.1 \pm 0.69$ \\
\hline
\end{tabular}

Value of mean of triplicate \pm standard error

Response to simulated stomach duodenum-passage (SSDP) (CFU/mL)

\begin{tabular}{llll}
\multicolumn{2}{l}{ Isolates } & \multicolumn{2}{l}{ Response to simulated stomach duodenum-passage $(\mathrm{SSDP})(\mathrm{CFU} / \mathrm{mL})$} \\
\cline { 2 - 4 } G14 & $\mathrm{h} r$ & $2 \mathrm{hr}$ & $4 \mathrm{hr}$ \\
G16 & $5.33 \pm 0.26$ & $3.43 \pm 0.12$ & $1.86 \pm 0.23$ \\
G20 & $6.26 \pm 0.26$ & $4.66 \pm 0.34$ & $3.26 \pm 0.27$ \\
G24 & $8.13 \pm 0.14$ & $7.46 \pm 0.23$ & $5.43 \pm 0.18$ \\
G32 & $9.36 \pm 0.14$ & $8.73 \pm 0.18$ & $8.06 \pm 0.26$ \\
\hline
\end{tabular}

Value of mean of triplicate \pm standard error

Table 10: Antibiotic susceptibility pattern of selected isolates

\begin{tabular}{|c|c|c|c|c|c|c|}
\hline \multirow[b]{2}{*}{ Antibiotics } & \multirow[b]{2}{*}{ Conc. $(\mathrm{mcg})$} & \multicolumn{5}{|c|}{ Bacterial isolates } \\
\hline & & G14 & G16 & G20 & $G 24$ & G32 \\
\hline Amikacin & 10 & S & $\mathrm{R}$ & $\mathrm{S}$ & $\mathrm{R}$ & $\mathrm{R}$ \\
\hline Carbenicillin & 100 & $\mathrm{R}$ & $\mathrm{R}$ & $\mathrm{R}$ & $\mathrm{R}$ & $\mathrm{S}$ \\
\hline Ciprofloxacin & 10 & $\mathrm{R}$ & $\mathrm{S}$ & $\mathrm{R}$ & $\mathrm{R}$ & $\mathrm{R}$ \\
\hline Co-trimazine & 25 & S & $\mathrm{R}$ & $S$ & S & $\mathrm{S}$ \\
\hline Kanamycin & 30 & S & $\mathrm{R}$ & $S$ & $\mathrm{R}$ & $\mathrm{R}$ \\
\hline Nitrofurantoin & 300 & $\mathrm{R}$ & $\mathrm{R}$ & $\mathrm{S}$ & $\mathrm{R}$ & $\mathrm{R}$ \\
\hline Streptomycin & 10 & $\mathrm{R}$ & S & $\mathrm{R}$ & $\mathrm{R}$ & $\mathrm{R}$ \\
\hline Tetracyclin & 30 & $\mathrm{R}$ & $\mathrm{S}$ & $\mathrm{R}$ & $\mathrm{R}$ & $\mathrm{R}$ \\
\hline
\end{tabular}

$\mathrm{R}=$ resistant; $\mathrm{S}$ = sensitive

percentage as compared to the isolates G14, G16, G20, and G32 (Table 7).

\section{Cell Surface Hydrophobicity}

Cell surface hydrophobicity is perceived as the quantifiable physicochemical factors to assess the adhesion of bacteria to the intestinal surface. Isolates were evaluated for cell surface properties toward hydrocarbons n-hexadecane and xylene. The bacterial isolates demonstrated a variable level of hydrophobicity. All isolates demonstrated good surface hydrophobicity; however, isolate G24 indicated the maximum hydrophobicity by $51.9 \%$ toward xylene, as compared to other isolates (Table 8).

\section{Response to Simulated Stomach Duodenum Passage (SSDP)}

Selected bacterial isolates were screened for protection to simulated stomach duodenum passage at an interval 


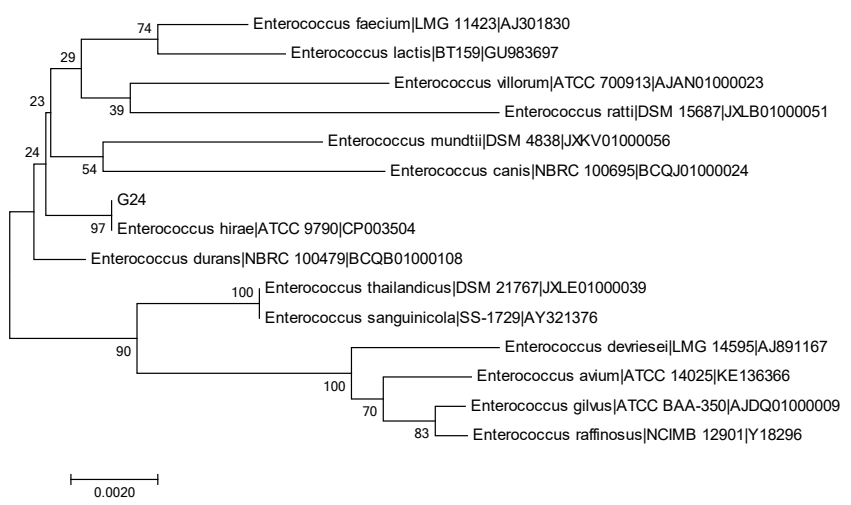

Fig. 1: Evolutionary relationships of taxa

The neighbor-joining method was used for evolutionary relationship of G24 following the neighbor-joining method, ${ }^{[1]}$ showing branch length of 0.05895749 of the optimal tree. The next to the branches show the percentage of replicate trees of the associated taxa clustered together in the bootstrap test (500 replicates). ${ }^{[2]}$ The evolutionary distances were analyzed by using the maximum composite likelihood method. ${ }^{[3]}$ It was analyzed by involving 15 nucleotides. All the 1,401 positions were eliminated, where gaps and missing data were present. The evolutionary relationship was analyses using MEGA7 software. ${ }^{[4]}$

of 2 and 4 hours. G24 indicated the most resistance as compared to other isolates (Table 9).

\section{Antibiotic Susceptibility Test}

Antibiotic susceptibility pattern of specific isolates was observed after the Kirby-Bauer disc technique. They were conveyed as sensitive (S) or resistant (R). Isolate G24 had higher resistance to the maximum antibiotics used because G24 did not form a zone of inhibition towards amikacin, carbenicillin, ciprofloxacin, kanamycin, streptomycin, tetracycline, and nitrofurantoin, but sensitive to co-trimazine (Table 10).

\section{Gelatinase Hydrolysis and Hemolytic Activity}

The potential probiotic bacteria must be non-toxic and non-pathogenic. The particular isolates were screened for gelatinase hydrolysis and hemolytic action. All selected isolates were confirmed by a zone of hemolytic and gelatinase hydrolysis activity because they did not demonstrate hemolytic and gelatinase hydrolysis action.

\section{Molecular Identification}

The most potential isolate G24 was identified as Enterococcus hirae based on 16S rRNA gene sequencing (accession number MK817656). The phylogenetic study established a close evolutionary similarity with $E$. hirae (Fig. 1). Therefore, the isolate G24 has been nominated in the test as E. hirae G24.

\section{DISCUSSION}

The main goal of this study, bacterial cultures isolated from goat milk were screened by biochemical characterization and probiotic attributes tests. The isolate G24 showing the best probiotic potential was identified as E. hirae G24.
Survival and multiplication in human gut is a significant basis for probiotic determination. The isolated bacteria adjust to grow optimally at $37^{\circ} \mathrm{C}$. The temperature can influence bacterial growth. All selected isolates were ingenious to survive at temperatures $4,15,25,37$, and $45^{\circ} \mathrm{C}$. The isolated bacteria were capable to survive within the selected temperature range of normal human gut or not, this was the reason for the selection of the temperature range. ${ }^{[27]}$ The probiotic isolates tolerated high salt concentrations up to $8 \% \mathrm{NaCl} . \mathrm{NaCl}$ may inhibit the growth of bacteria because this is an inhibitory substance. If the isolates are sensitive to $\mathrm{NaCl}$, it would not be able to demonstrate the activity at this concentration. The LAB is mostly classified as a homo/ heterofermentative, according to their by-products of sugar fermentation. Homofermantative lactic acid bacteria are formed lactic acid as the prime by-product of glucose. Heterofermantative lactic acid bacteria are produced lactic acid, ethanol, acetic acid, and carbon dioxide $\left(\mathrm{CO}_{2}\right)$ from glucose. Based on these characteristics, E. hirae G24 was identified as homofermentative bacteria.

Probiotic microbes are exposed to different adverse conditions, such as, acidic and alkaline conditions during passage through the gastrointestinal tract in the human gut. Therefore, lab needs to tolerate low $\mathrm{pH}$ of the human gut to be considered as probiotics. Food digestion can take up to 3 hours in the stomach, but stomach $\mathrm{pH}$ ranged from 1 (during fasting) to 4.5 (after a meal). The small intestine of the host is enhanced by metabolic activity and colonization of bacteria, which is considered a criterion for tolerance of bile salt. From the catabolism of cholesterol, bile salts are produced in the liver, which are surface active chemicals. Bile salt $(2 \%)$ represents the extreme concentration obtained in animals or human intestines during the first hour of digestion; the normal level of bile salt in the intestine is around $0.3 \%{ }^{[28]}$ Therefore, while assessing the potential of lab as active probiotics, it is commonly observed as important to assess their capacity to resist the impacts of bile acids. E. hirae G24 was more resistance to bile, low $\mathrm{pH}$, and phenol. Resistance to $0.4 \%$ phenol was further a significant test conducted for checking the survival of probiotic bacteria under gastrointestinal conditions. Phenol concentration is a toxic metabolite formed by deamination of some amino acids during disintegration by intestinal bacteria. [29]

Auto-aggregation and cell surface hydrophobicity are in vitro methods to test the adhesive capacity of the probiotics. The removal of pathogens by biofilm formation is a significant role of aggregation ability of probiotic bacterium into the gut. ${ }^{[30]}$ Cell surface hydrophobicity is a non-specific interaction between microbial cells and host including cell surface protein and lipoteichoic acids. Determination of the ability to adhere to the oral cavity, gastrointestinal tract, and urogenital tract by probiotic strain is an important factor. ${ }^{[31]}$ E. hirae G24 
under investigation was able to demonstrate cell surface hydrophobicity and aggregation activity, which is a good sign of probiotic property.

Probiotic bacteria produced antimicrobial compounds including organic acids, hydrogen peroxide, bacteriocins, which is an excellent feature for modulation of intestinal microbiota. Probiotic bacterial produced antimicrobial substances affect pathogenic bacterial metabolism or toxin production. The absence of antibiotic-resistant genes in bacteria is a certain characteristic for probiotics. Resistance probiotic bacteria do not have those genes which can be transferred to other bacterial population by conjugation. Although, research has shown that intestinal strains have more resistance. ${ }^{[32]}$ During our study, E. hirae G24 formed the highest zone of inhibition against bacterial pathogens and was antibiotic-resistant. Accordance through FAO/WHO, the absence of hemolytic activity, and gelatinase hydrolysis as a safety assessment for the selection of probiotic strains. ${ }^{[33]}$ In this study, E. hirae G24 was displayed the nonappearance of hemolytic activity and gelatinase hydrolysis. So, it is safe for the use in food products, food supplements as probiotics.

\section{CONCLUSION}

It might be reasoned that E. hirae G24 accomplished all the properties required for a good probiotic such as tolerance to high salt, low $\mathrm{pH}$, bile salt concentrations, phenol resistance, and antibiotic resistance. This probiotic strain can produce an antimicrobial product that inhibits the pathogenic organisms. So, E. hirae G24 may be considered the potential to be used as probiotic to protect the aspect of health stimulating effects. This probiotic strain can be used in dairy industries, the advancement of pharmaceutical products, and therapeutic purposes.

\section{ACKNOWLEDGEMENTS}

The authors are thankful to the Head, Department of Botany and Microbiology, Gurukula Kangri Vishwavidyalaya, Haridwar for providing the research lab facilities.

\section{REFERENCES}

1. Quigley L, O' sullivan O, Stanton C, Beresford TP, Ross RP, Fitzgerald $\mathrm{GF}$, et al. The complex microbiota of raw milk. FEMS Microbiology Reviews. 2013;37(5):664-698.

2. Park YW. Bioactive components in goat milk. Bioactive components in milk and dairy products. 2009; p. 43-81.

3. Park YW. Rheological characteristics of goat and sheep milk. Small Ruminant Research. 2007;68(1-2):73-87.

4. Moreno MF, Sarantinopoulos P, Tsakalidou E, De Vuyst L. The role and application of Enterococci in food and health. International Journal of Food Microbiology. 2006;106(1):1-24.

5. Hu Y, Dun Y, Li, S, Zhang, D, et al. Dietary Enterococcus faecalis LAB31 improves growth performance, reduces diarrhea, and increases fecal Lactobacillus number of weaned piglets. PLoS One. 2015;10(1):1-16.

6. Vinderola G, Capellini B, Villarreal F, Suárez V, Quiberoni A, Reinheimer J. Usefulness of a set of simple in vitro tests for the screening and identification of probiotic candidate strains for dairy use. LWT-Food Science and Technology. 2008;41(9):16781688.

7. Singh K, Kallali B, Kumar A, Thaker V. Probiotics: A review. Asian Pacific Journal of Tropical Biomedicine. 2011;1(2):287-290.

8. Pessione E. Lactic acid bacteria contribution to gut microbiota complexity: lights and shadows. Frontiers in Cellular and Infection Microbiology. 2012;86(2):1-15.

9. Liong MT. Probiotics: a critical review of their potential role as antihypertensives, immune modulators, hypocholesterolemics, and perimenopausal treatments. Nutrition Reviews. 2007;65(7):316-328.

10. Choudhary J, Dubey RC, Sengar G, Dheeman S. Evaluation of probiotic potential and safety assessment of Lactobacillus pentosus MMP4 isolated from mare's lactation. Probiotics and Antimicrobial Proteins. 2018;11(2):403-412.

11. Bhattacharyya BK. Emergence of probiotics in therapeutic applications. International Journal of Pharmaceutical Sciences and Nanotechnology. 2009;2(1):383-389.

12. Saxelin M. Probiotic formulations and applications, the current probiotics market, and changes in the marketplace: a European perspective. Clinical Infectious Diseases. 2008;46(2):76-79.

13. Marroki A, Zúñiga M, Kihal M, Pérez-Martínez G. Chaacterization of Lactobacillus from Algerian goat's milk based on phenotypic, 16S rDNA sequencing and their technological properties. Brazilian Journal of Microbiology. 2011;42(1):158-171.

14. Gupta A, Tiwari SK. Probiotic potential of Lactobacillus plantarum LD1 isolated from batter of Dosa, a South Indian fermented food. Probiotics and Antimicrobial Proteins. 2014;6(2):73-81.

15. Hedberg M, Hasslöf P, Sjöström I, Twetman S, Stecksén-Blicks C. Sugar fermentation in probiotic bacteria-an in vitro study. Oral Microbiology and Immunology. 2008;23(6):482-485.

16. Tambekar DH, Bhutada SA. An evaluation of probiotic potential of Lactobacillus sp. from milk of domestic animals and commercial available probiotic preparations in prevention of enteric bacterial infections. Recent Research in Science and Technology. 2010;2(10): 82-88.

17. Ramos MA, Weber B, Gonçalves JF, Santos GA, Rema P, Ozório ROA. Dietary probiotic supplementation modulated gut microbiota and improved growth of juvenile rainbow trout (Oncorhynchus mykiss). Comparative Biochemistry and Physiology. Part A, Molecular and Integrative Physiology. 2013;166(2):302-307.

18. Xanthopoulos V, Litopoulou-Tzanetaki E, Tzanetakis N. In vitro study of Lactobacillus species strains on bile tolerance and cholesterol removal. Lactic acid bacteria-lactic. 1997;p. 97.

19. Vatanyoopaisarn S, Prapatsornwattana K, Kuhakongkeat T, Phalakornkule C. Potential use of lactic acid bacteria with bacteriocin-like activity against Staphylococcus aureus as dual starter cultures in Thai fermented sausage" Sai Krok Prew." International Food Research Journal. 2011;18(2):697-704.

20. Kos BVZE, Šušković J, Vuković S, Šimpraga M, Frece J, Matošić S. Adhesion and aggregation ability of probiotic strain Lactobacillus acidophilus M92. Journal of Applied Microbiology. 2003;94(6): 981-987.

21. Vinderola CG, Reinheimer JA. Lactic acid starter and probiotic bacteria: a comparative "in vitro" study of probiotic characteristics and biological barrier resistance. Food Research International. 2003;36(9-10):895-904.

22. Mathara JM, Schillinger U, Guigas C, Franz C, Kutima PM, Mbugua $\mathrm{SK}$, et al. Functional characteristics of Lactobacillus spp. from traditional Maasai fermented milk products in Kenya. International Journal of Food Microbiology. 2008;126(1-2):57-64.

23. National Committee for Clinical Laboratory Standard. Performance standards for antimicrobial disc susceptibility tests. Approved Standard M2-A5, $5^{\text {th }}$ Ed.Villanova: NCCL 1993.

24. Harrigan WF, McCance ME. Laboratory methods in food and dairy microbiology, Academic Press Inc. London, United Kingdom 1990; p. $170-210$.

25. Pieniz S, Andreazza R, Anghinoni T, Camargo F, Brandelli A. Probiotic potential, antimicrobial and antioxidant activities of 
Enterococcus durans strain LAB18s. Food Control. 2014;37:251-256. 26. Sambrook J, Russell DW. Molecular Cloning-Sambrook and RusselVol. 1, 2, 3. Cold Springs Harbor Laboratory Press 2001.

27. Pundir RK, Rana S, Kashyap N, Kaur A. Probiotic potential of lactic acid bacteria isolated from food samples: an in vitro study. Journal of Applied Pharmaceutical Science. 2013;3(3):85-93.

28. Wang J, Guo Z, Zhang Q, Yan L, Chen W, Liu XM, et al. Fermentation characteristics and transit tolerance of probiotic Lactobacillus casei Zhang in soymilk and bovine milk during storage. Journal of Dairy Science. 2009;92(6):2468-2476.

29. Sathyabama S, Vijayabharathi R. Co-encapsulation of probiotics with prebiotics on alginate matrix and its effect on viability in simulated gastric environment. LWT-Food Science Technology. 2014;57(1):419-425.
30. Austin JW, Sanders G, Kay WW, Collinson SK. Thin aggregative fimbriae enhance Salmonella enteritidis biofilm formation. FEMS Microbiology Letters. 1998;162(2):295-301.

31. Todorov SD, Furtado DN, Saad SMI, Tome E, Franco BDGDM. Potential beneficial properties of bacteriocin-producing lactic acid bacteria isolated from smoked salmon. Journal of Applied Microbiology. 2011;110(4):971-986.

32.Zhou T, Zhang W, Sweiss NJ, Chen ES, Moller DR, Knox KS, et al. Peripheral blood gene expression as a novel genomic biomarker in complicated sarcoidosis. PloS one. 2012;7(9):1-13.

33. FAO/WHO. Guideline for the evaluation of probiotics in food: Report of a joint $\mathrm{FAO} / \mathrm{WHO}$ working group on drafting guideline for the evaluation of probiotics in food. (London, Ontario, Canada). Food Research International. 2002;54(1):118-124.

HOW TO CITE THIS ARTICLE: Rajput K, Dubey RC. Probiotic potential and safety characterization of Enterococcus hirae G24 isolated from indigenous raw goat milk. Int. J. Pharm. Sci. Drug Res. 2020;12(3):218-226. D0I: 10.25004/IJPSDR.2020.120303 